\title{
Editorial
}

A equipe editorial da Revista do Serviço Público (RSP) tem o prazer de apresentar a seus leitores o terceiro número do septuagésimo primeiro volume.

"Incentivos importam", destacou, em seus estudos, Douglass North, o falecido historiador econômico e, desde então, muito se tem estudado sobre o papel dos incentivos em diversos contextos. Incentivos, vale lembrar, neste contexto, dizem respeito às regras que constrangem as ações dos indivíduos. Seu insight não se restringe, obviamente, ao setor privado. Aqueles que conhecem um pouco do setor público sabem que o (des) alinhamento de incentivos não é um problema que passe despercebido. O papel dos incentivos é alvo dos cinco primeiros artigos deste número.

Tome-se por exemplo o caso do primeiro artigo, em que se busca entender quais incentivos afetam a evasão em uma das carreiras do serviço público do Estado de Minas Gerais: a dos Especialistas em Políticas Públicas e Gestão Governamental. Aparentemente, a insatisfação salarial aliada à possibilidade de outros concursos públicos tem levado a uma realocação intrassetor público, com prejuízo da gestão pública mineira.

O segundo artigo também trata do problema de incentivos, mas no serviço público federal. Por meio de estudo baseado em uma amostra de dois mil e oitocentos servidores públicos, encontram-se evidências de que aqueles em início de carreira percebem mais benefícios alocando seu tempo para estudar para concursos que thes retornem maior remuneração do que na sinalização de que são servidores empenhados em suas tarefas ("servir ao público").

No terceiro artigo, o problema dos incentivos reaparece na questão principal do estudo: qual o estado da arte da pesquisa nacional sobre o comprometimento entre servidores públicos e suas organizações? Em outras palavras, o que dizem as pesquisas sobre o comprometimento organizacional dos servidores brasileiros? A revisão da literatura encontrou uma pequena, mas aparentemente crescente, produção (notadamente a partir de 2012), representada por 77 artigos científicos nacionais, no período 1989-2019. É mais uma evidência de que o papel dos incentivos na gestão pública é uma área promissora de estudos.

O quarto artigo tem como foco a avaliação de resultados e desempenho no Sistema Único de Saúde (SUS). Por meio de painéis colaborativos, foram coletadas informações de 220 gestores e profissionais de saúde. A base de dados foi submetida à análise fatorial com a validação final de 17 indicadores que podem servir para um futuro instrumento de avaliação.

O quinto artigo deste número analisa a relação entre direitos humanos e políticas públicas por meio das recomendações e soluções amistosas da Comissão Interamericana 
de Direitos Humanos, em seu relatório de 2017. Verifica-se que a comissão e seus estadosmembros têm preferências distintas em relação às "ferramentas" utilizadas, o que ilustra o difícil problema de alinhamento de incentivos em organizações.

Ora, se incentivos importam e o alinhamento de interesses é um problema central em um ambiente no qual a assimetria informacional não é um fenômeno raro, o meio para se tentar o desenho ideal dos incentivos são as organizações, sejam elas públicas ou privadas. A heterogeneidade das preferências daqueles envolvidos em processos organizacionais é um desafio para qualquer planejamento. A análise de organizações é a tônica subjacente ao sexto artigo deste número.

Esse lança um olhar sobre a gestão do conhecimento na Comissão de Implantação do Sistema do Controle do Espaço Aéreo (Ciscea). Fazendo uso de questionário aplicado a 25 militares da comissão, encontra-se que a gestão do conhecimento estaria em um nível de maturidade intermediário, com destaque positivo para práticas associadas à aprendizagem e inovação.

Como já dito, o alinhamento de interesses é um problema central de incentivos em organizações. Não seria diferente no intrincado jogo democrático. A comunicação entre eleitores e eleitos é o leitmotiv do sétimo artigo. As evidências apontam para um baixo grau de comunicação por meio dos endereços de correio eletrônico oficiais dos 513 deputados federais da legislatura atual ${ }^{1}$.

Por fim, o oitavo artigo toca em um ponto que tem se tornado mais presente no debate público nos últimos anos, notavelmente em consequência da generalização do uso da internet: a segurança cibernética. Analisando 35 órgãos da administração pública federal, encontra-se um preocupante baixo grau de maturidade em relação à segurança cibernética. Diante do resultado, os autores propõem o desenvolvimento de um modelo de maturidade de segurança cibernética.

Como de hábito, esperamos que este novo número da RSP traga ao nosso leitor novos e interessantes insights.

\section{Diana Coutinho}

Editora-chefe

Claudio D. Shikida

Editor-adjunto

\footnotetext{
${ }^{1}$ Além disso, verifica-se que parlamentares não parecem muito dispostos a responder a mensagens com conteúdos considerados "polêmicos", o que, lembram esses editores, é uma evidência compatível com a Teoria do Eleitor Mediano.
} 